\title{
Viral geography and global risks: the circulation of health risks in the context of global health governance
}

\section{Gabriel Blouin Genest and Rebecca Sherrod}

\section{OpenEdition}

\section{Journals}

Electronic version

URL: http://journals.openedition.org/rfst/822

DOI: $10.4000 /$ rfst.822

ISSN: 2492-3672

\section{Publisher}

Espaces et SOciétés (UMR 6590)

\section{Electronic reference}

Gabriel Blouin Genest and Rebecca Sherrod, "Viral geography and global risks: the circulation of health risks in the context of global health governance", Revue francophone sur la santé et les territoires [Online], Healthy circulation: products, knowledge, people on the move, Online since 12 December 2019, connection on 06 April 2021. URL: http://journals.openedition.org/rfst/822 ; DOI: https://doi.org/ $10.4000 /$ rfst.822

This text was automatically generated on 6 April 2021.

\section{C) (1)}

La Revue francophone sur la santé et les territoires est mise à disposition selon les termes de la Licence Creative Commons Attribution - Pas d'Utilisation Commerciale - Partage dans les Mêmes Conditions 4.0 International. 


\title{
Viral geography and global risks: the circulation of health risks in the context of global health governance
}

\author{
Gabriel Blouin Genest and Rebecca Sherrod
}

1 It is widely asserted that we live today in a globalized world governed by dense flows and constant fluidity, structuring as such a generalized perception of hypermobility. The field of public health is not immune to this trend, particularly when it comes to global health and its governance mechanisms. Viruses, diseases, germs and other health "risks" are presented in this perspective as global and hypermobile threats that ignore territorial demarcations, borders and politics, potentially spreading instantly around the world. Our common world is one of endless threats in circulation and for which global governance is presented as an obligatory passage point in terms of responses and interventions. Such "viral geography" however raises many questions, among which that of the effectiveness of global governance appears the most pressing. This is especially true when it comes to the prioritization process in which other health risks are not taken into consideration by the global health governance apparatus led, among other actors, by the World Health Organization (WHO), among other actors. In particular, this system risks favouring certain types of health risks and hazards, to the disadvantage of others, a phenomenon which is, however, not officially recognized by global health actors, rendering more than necessary to conduct an empirical analysis of the output of global health governance necessary.

2 The purpose of this article is to critically engage with the interaction and interference between geography and global health governance practices, looking in particular at the surveillance activities of the WHO under the new International Health Regulations (IHR) adopted in 2005, which and that radically changed the practices and impacts of global health governance. The adoption of a new IHR in 2005 completed a deep process of revision initiated in 1995. in It was undertaken in response to both political changes brought in on by the end of the Cold War and the emergence of globalization in which risks, in parallel with the other products of globalization (goods, ideas, finance, etc.),

Revue francophone sur la santé et les territoires, Les circulations en santé : des produits, des savoirs, des personnes en mouvement 
where seen as circulating freely, bringing new threats that should be addressed at the global level. Circulation, risks and geography maintain, as we argue in this article, a symbiotic relationship that today defines the dominant understanding of a global sanitary space, and by the same token, the rationality of its global health governance mechanisms. This Its rationale is found in particular in the different narratives justifying the actions and practices of the $\mathrm{WHO}$ as the main actor in the planning and implementation of global health governance, as well as in the production of a specific understanding of risks in circulation, a phenomenon which is documented in this article. We thus question the interaction between a particular understanding of health risks in circulation (through the communication tools of the WHO) and their use to justify political practices and interventions at the global level. This article thus explores this relationship through three particular analytical and empirical spaces. We first focus our attention on the changes brought about by the new IHR 2005 and the different interpretations that have been made by scholars and practitioners. In a second step, we problematize the practice of this global health governance apparatus through the lenses of a quantitative analysis of its output, using the WHO surveillance data produced by the Disease Outbreak News system. Finally, we take a critical look at the circulation, spatiality and geography of health risks and threats in the context of globalization, thus resituating circulation at the heart of the justifications of global health governance. We conclude by with a problematization of the impacts of the transition from the notion of risk to that of danger, a phenomenon that, we argue, characterizes, we argue in this paper, contemporary global governance.

Figure 1: The most important health issues identified by the WHO surveillance system

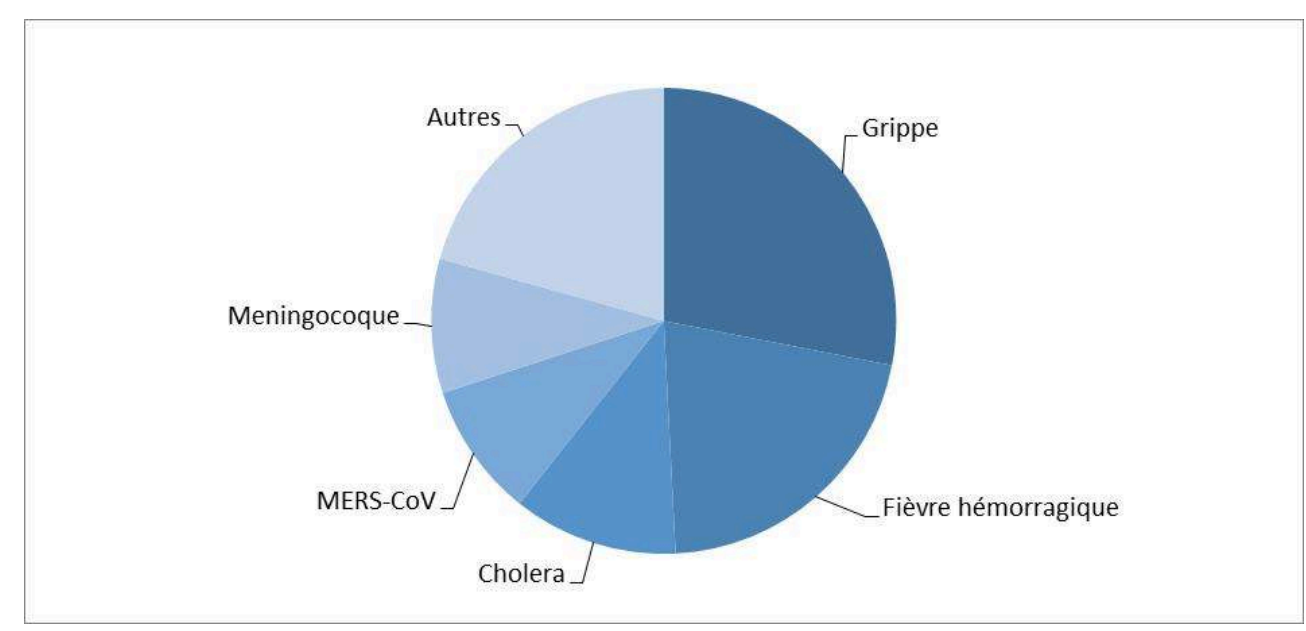

Revue francophone sur la santé et les territoires, Les circulations en santé : des produits, des savoirs, des personnes en mouvement 
Table 1: Comparison of diseases under surveillance and diseases with the highest health impacts (2016)

\begin{tabular}{|c|c|}
\hline Top 10 diseases under WHO surveillance (2016) & Top 10 diseases in terms of DALY's (2016) \\
\hline MERS-COV & Respiratory infections \\
\hline Influenza & Diarrhea \\
\hline Zika & HIV/AIDS \\
\hline Yellow fever & Tuberculosis \\
\hline Lassa Fever & Malaria \\
\hline Syndrome Guillain-Barre & Meningitis \\
\hline Microcephaly & $\begin{array}{l}\text { Childhood-related diseases (Pertussis, Poliomyelitis, } \\
\text { Diphtheria, Measles, and Tetanus) }\end{array}$ \\
\hline Chikungunya & $\begin{array}{l}\text { Sexually transmitted infections, excluding HIV/AIDS } \\
\text { (Syphilis, Chlamydia and Gonorrhea) }\end{array}$ \\
\hline Dengue fever & Hepatitis (A, B, C, D) \\
\hline Polio & Encephalitis \\
\hline
\end{tabular}

INDEX

Keywords: risk, global health governance, circulation

\section{AUTHORS}

\section{GABRIEL BLOUIN GENEST}

Professeur Adjoint École de politique appliquée, Université de Sherbrooke, Québec, Canada

\section{REBECCA SHERROD}

Virginia Tech, Blacksburg, VA, USA 